\title{
PEMANFAATAN TUMBUHAN TRADISIONAL SEBAGAI OBAT DIARE PADA MASYARAKAT KECAMATAN TERANGUN KABUPATEN GAYO LUES
}

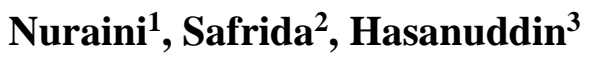 \\ Program Studi Pendidikan Biologi Fakultas Keguruan dan Ilmu Pendidikan \\ Universitas Syiah Kuala Darussalam, Banda Aceh \\ Gmail: nuraini.bio16@fkip.unsyiah.ac.id
}

\begin{abstract}
ABSTRAK
Penelitian ini bertujuan untuk mengetahui (1) mengetahui jenis tumbuhan tradisional yang dimanfaatkan sebagai obat diare pada masyarakat Kecamatan Terangun Kabupaten Gayo Lues (2) bagian tumbuhan yang akan dijadikan sebagai obat diare (3)cara pengolahan tumbuhan tradisional sebagai obat diare pada masyarakat Kecamatan Terangun Kabupaten Gayo Lues (4) persepsi masyarakat Kecamatan Terangun Kabupaten Gayo Lues memanfaatkan tumbuhan tradisional sebagai obat diare. Pengumpulan data telah dilakukan di Kecamatan Terangun Kabupaten Gayo Lues pada Bulan Oktober 2020 sampai April 2021. Penelitian menggunakan metode kualitatif dengan jenis penelitian wawancara, angket dan observasi. Hasil penelitian menunjukan bahwa jenis-jenis tumbuhan tradisional yang digunakan sebagai obat diare di Kecamatan Terangun Kabupaten Gayo Lues terdapat 40 jenis tumbuhan dari 27 familia. Jenis tumbuhan paling banyak digunakan yaitu jambu biji dengan persentase $100 \%$ atau kriteria sangat tinggi. Bagian atau organ tumbuhan obat yang digunakan sebagai obat diare yaitu siung, batang, kulit batang, daun, tangkai bunga, bunga, rimpang, kulit buah, buah dan biji. Bagian tumbuhan yang paling banyak digunakan yaitu bagian daun dengan persentase $31,01 \%$ atau dengan kriteria rendah. Cara pengolahan tumbuhan tradisional sebagai obat diare yaitu dengan cara digiling, direbus, diremas dan diperas. Cara pengolahan tumbuhan sebagai obat diare paling banyak dilakukan dengan cara digiling dengan persentase 57,67 \% atau dengan kriteria tinggi. Persepsi masyarakat menggunakan tumbuhan tradisional untuk obat diare di Kecamatan Terangun Kabupaten Gayo Lues bahwa persepsi yang banyak timbul adalah tumbuhan tradisional dijamin aman untuk mengobati diare dengan persentase $98,33 \%$ atau dengan kriteria sangat setuju.
\end{abstract}

Kata Kunci : Tumbuhan Tradisional, Obat diare, Kecamatan Terangun, Kabupaten GayoLues

\section{ABSTRACT}

This study aims to determine (1) the types of traditional plants used as diarrhea medicine in the people of Terangun District, Gayo Lues Regency (2) the parts of the plant that will be used as diarrhea medicine (3) how to process traditional plants as diarrhea medicine in the people of Terangun District, Gayo Lues Regency (4) perception of the people in Terangun District, Gayo Lues Regency in using traditional plants as diarrhea medicine. Data collection has been carried out in Terangun District, Gayo Lues Regency from October 2020 to April 2021. This study uses a qualitative method by employing interviews, questionnaires and observations. The results showed that the types of traditional plants used as diarrhea medicine in Terangun District, Gayo Lues Regency were 40 plant species from 27 families. The most widely used plant species is guava with 
a percentage of $100 \%$ or very high criteria. Parts or organs of medicinal plants used as diarrhea medicine are cloves, stems, bark, leaves, flower stalks, flowers, rhizomes, fruit skins, fruits and seeds. The most widely used plant parts are the leaves with a percentage of $31.01 \%$ or with low criteria. The traditional way of processing plants as diarrhea medicine is by grinding, boiling, kneading and squeezing. The method of processing plants as diarrhea medicine is mostly done by grinding with a percentage of $57.67 \%$ or with high criteria. The most common public perception of the use of traditional plants for diarrhea medicine in Terangun District, Gayo Lues Regency is that traditional plants are guaranteed to be safe for treating diarrhea with a percentage of $98.33 \%$ or with strongly agree criteria.

Keywords: Traditional Plants, Diarrhea medicine, Terangun District

\section{PENDAHULUAN}

Indonesia merupakan salah satu negara megabiodiversity terbesar di dunia yang kaya akan sumber daya hayati. Kekayaan alam tumbuhan di negara ini diperkirakan meliputi 30.000 spesies, 940 spesies diantaranya merupakan tumbuhan yang berkhasiat obat . Tumbuhan obat merupakan tumbuhan berkhasiat obat yang dapat menghilangkan rasa sakit, meningkatkan daya tahan tubuh dan membunuh bibit penyakit. Bagian tanaman obat yang biasanya digunakan berupa akar, kulit batang, kayu, daun, bunga atau bijinya (Rapilu dan Watuguly, 2018:54).

Pemanfaatan tumbuhan obat ini telah dikenal secara turun temurun oleh masyarakat Indonesia untuk mengobati berbagai penyakit salah satunya ialah penyakit diare. Larasati (2016:424) mengatakan diare adalah salah satu masalah kesehatan yang sering menyerang masyarakat berbagai usia, bahkan diare dapat menyebabkan kehilangan elektrolit, dehidrasi, shock dan bahkan kematian. Diare menyebabkan kematian pada 1 dari 9 sembilan anak penderita diare, menyebabkan diare menjadi penyebab kematian nomor dua di dunia terhadap anak dibawah usia 5 tahun. Diare dapat diatasi denga berbagai cara diantaranya ialah membiasakan pemanfaatan tumbuhan tradisional.

Pengobatan dan pemanfaatan berbagai jenis tumbuhan obat oleh suatu masyarakat merupakam potensi yang harus tetap dijaga kelestariannya, selain faktor murah, pengaruh sampingan yang rendah juga sesuai dengan kondisi dari sarana dan prasarana kesehatan, dikhawatirkan penggunaan obat secara tradisional akan semakin berkurang bahkan hilang, begitu pula dengan populasi dan keberadaan jenis tumbuhan obat akan ikut terancam karena tidak lagi dimanfaatkan dan dipelihara. 
Namun masih terdapat masyarakat yang menggunakan tumbuhan obat untuk mengobati penyakit yaitu masyarakat Suku Gayo khususnya yang terdapat di Kecamatan Terangun Kabupaten Gayo Lues.

Kecamatan Terangun Kabupaten

Gayo Lues dipilih untuk lokasi penelitian karena terletak didekat hutan yang banyak terdapat tanaman obat salah satunya obat anti diare. Dimana batasa-batas wilayahnya sebelah utara berbatasan dengan Kab, Aceh Barat Daya, sebelah selatan Kecamatan Tripe Jaya, sebelah barat berbatasan dengan Kabupaten Abdia dan sebelah timur berbatasan dengan Kecamatan Blangjerango dengan luas daerah $11.0756 \mathrm{~km} 2$.

Masyarakat suku Gayo merupakan masyarakat yang majemuk, sebagian besar penduduknya adalah petani serta berlatar pendidikan yang berbeda-beda mulai dari tingkat kelulusan SD sampai pengguruan tinggi. Berdasarkan hasil pengamatan sementara, masyarakat suku Gayo sebagian besar memiliki pemahaman tentang pemanfaatan tumbuhan obat tradisional untuk mengobati berbagai jenis penyakit yang diderita termasuk penyakit diare, bahkan ada sebagian masyarakat yang secara khusus dapat dikategorikan sebagai ahli tumbuhan obat tradisional, karena mereka secara praktis dapat mengobati orang lain dengan tumbuhan obat tradisional. Atas dasar ini penelitian ini penting diteliti agar dapat memberikan informasi kepada masyarakat maupun pemerintahan bahwa terdapat jenisjenis tumbuhan obat di Suku Gayo yang dapat digunakan sebagai obat tradisional.

Terdapatnya berbagai tumbuhan yang dapat dimanfaatkan sebagai obat penyembuhan penyakit telah dibuktikan oleh beberapa kajian terdahulu seperti Yasir dan Asnah (2018) yang mengkaji pemanfaatan tanaman obatan tradisional pada masyarakat Aceh Tenggara mengatakan bahwa ditemukan 46 spesies dari 30 familia Jenis Tumbuhan Obat Tradisional yang dapat dimanfaatkan di Desa Batu Hamparan Kabupaten Aceh Tenggara. Berdasarkan penjelasan di atas maka peneliti tertarik untuk melakukan penelitian dengan judul "Pemanfaatan Tumbuhan Tradisional Sebagai Obat Diare Pada Masyarakat Kecamatan Terangun Kabupaten Gayo Lues".

\section{METODE PENELITIAN}

Jenis penelitian yang digunakan dalam penelitian ini yaitu penelitian kualitatif. Metode yang digunakan dalam penelitian ini adalah dengan metode wawancara, angket dan observasi yang dilakukan di Kecamatan Terangun 
Kabupaten Gayo Lues pada bulan Oktober 2020 - November 2020.

\section{HASIL PENELITIAN DAN} PEMBAHASAN

Hasil penelitian yang telah dilakukan mengenai pemanfaatan tumbuahan tradisional sebagai obat diare pada masyarakat Kecamatan Terangun Kabupaten Gayo Lues.

Jenis Tumbuhan Tradisional yang Dijadikan Sebagai Obat Diare

Berdasarkan hasil penelitian yang telah dilakukan pada 6 Desa di Kecamatan
Terangun Kabupaten Gayo Lues deangan mewawancarai 60 responden serta observasi yang dilakukan di lokasi penelitian terdapat 40 spesies yang terdiri 28 familia yang dapat digunakan sebagai tumbuhan tradisional sebagai obat diare. Tumbuhan ini dapat diperoleh dari pekarangan rumah, perkebunan yang sengaja ditanam, dihutan dan dirawat dengan baik oleh masyarakat serta membeli bahan yang tidak ada di pasar. Dari hasil penelitian dapat diketahui bahwa masyarakat masih menggunakan tumbuhan sebagai obat diare. hal ini dapat dilihat pada Tabel 1.

Tabel 1. Jenis Tumbuhan Tradisional yang Dijadikan Sebagai Obat Diare Di Kecamatan Terangun Kabupaten Gayo Lues.

\begin{tabular}{|c|c|c|c|c|}
\hline No & Nama daerah & Nama & Nama ilmiah & Family \\
\hline 1 & Kuning & Kunyit & Curcuma longa $\mathrm{L}$. & Zingiberaceae \\
\hline 2 & Asam kuyun & Jeruk nipis & $\begin{array}{l}\text { Citrus aurantifolia } \\
\text { (Christm.) Swingle }\end{array}$ & Rutaceae \\
\hline 3 & $\mathrm{Tu}$ & Tebu & $\begin{array}{l}\text { Saccharum officinarum } \\
\text { L. }\end{array}$ & Graminae \\
\hline 4 & Bebeke & Sanggani & $\begin{array}{l}\text { Melastoma } \\
\text { malabathrikum L. }\end{array}$ & Melastomaceae \\
\hline 5 & Keramil & Kelapa & Cocos nucifera $\mathrm{L}$. & Arecaceae \\
\hline 6 & $\mathrm{Kacu}$ & Gambir & $\begin{array}{l}\text { Uncaria macrophylla } \\
\text { Wall. }\end{array}$ & Rubaceae \\
\hline 7 & Awal & Pisang & Musa paradisiaca L. & Musaceae \\
\hline 8 & Mangga & Mangga & Mangifera indica L. & Anocardiaceae \\
\hline 9 & Gelime & Jambu biji & Psidium guajava $\mathrm{L}$. & Mirtaceae \\
\hline 10 & Buah pala & Buah pala & Myristica fragrans Houtt. & Myristicaceae \\
\hline 11 & Pangoh & Aren & $\begin{array}{l}\text { Arenga pinnata (Wurm) } \\
\text { Merr }\end{array}$ & Arecaceae \\
\hline 12 & Reruku & Ruku-ruku & Ocimum tenuiflorum $\mathrm{L}$. & Lamiaceae \\
\hline 13 & Nangka & Nangka & $\begin{array}{l}\text { Artocarpus heterophyllus } \\
\text { Lam. }\end{array}$ & Moraceae \\
\hline 14 & Cekala & Kecombrang & $\begin{array}{l}\text { Etlingera elatior }(\text { Jack) } \\
\text { R.M.Sm. }\end{array}$ & Zingiberaceae \\
\hline
\end{tabular}




\begin{tabular}{|c|c|c|c|c|}
\hline 15 & $\begin{array}{l}\text { Bunge } \\
\text { lawang }\end{array}$ & Cengkeh & $\begin{array}{l}\text { Syzygium aromaticum (L) } \\
\text { Merr. \& L.M.Perry. }\end{array}$ & Mirtaceae \\
\hline 16 & Ketumer & Ketumbar & Coriandrum sativum $\mathrm{L}$. & Apiaceae \\
\hline 17 & Jeremanis & Jintan putih & Cuтіпит сутіпит L. & Apiaceae \\
\hline 18 & Lede pedih & Lada hitam & Piper nigrum $\mathrm{L}$. & Piperaceae \\
\hline 19 & Lasun putih & Bawang putih & Allium sativum $\mathrm{L}$. & Alliaceae \\
\hline 20 & Belo & Daun sirih & Piper betle $\mathrm{L}$. & Piperaceae \\
\hline 2 & Baing & Jahe & Zigiber officinale Roscoe. & Zingiberaceae \\
\hline 2 & Pinang & Pinang & Areca catechu $\mathrm{L}$. & Arecaceae \\
\hline 23 & Tekur & Kencur & Kaempferia galaga $\mathrm{L}$. & Zingiberaceae \\
\hline 2 & Kayu manis & Kayu manis & $\begin{array}{l}\text { Cinnamoтиm burmannii } \\
\text { (Ness \& T.Ness) Blume }\end{array}$ & Lauraceae \\
\hline 25 & Mungkur & Jeruk purut & Citrus hystrix DC. & Rutaceae \\
\hline 2 & Durin belene & Sirsak & Annona muricata L. & Annonaceae \\
\hline 27 & Labu jepan & Labu siam & $\begin{array}{l}\text { Sechium edule (Jacq.) } \\
\text { SW. }\end{array}$ & Cucurbitaceae \\
\hline 28 & Gadung uyet & Ubi jalar & $\begin{array}{l}\text { Ipomoea batatas (L.) } \\
\text { Lam. }\end{array}$ & $\mathrm{C}$ \\
\hline 29 & Kayu benalu & Benalu & $\begin{array}{l}\text { Loranthus europhaeus } \\
\text { Jacq. }\end{array}$ & Loranthaceae \\
\hline 30 & Ramuten & Rambutan & Nephelium lappaceum L. & Sapindaceae \\
\hline 31 & Gadung kayu & Ubi ka & $\begin{array}{l}\text { Manihot esculenta } \\
\text { Crantz. }\end{array}$ & Euphorbeaceae \\
\hline 32 & Lempuyang & Lempuyang & $\begin{array}{l}\text { Zingiber zerumber (L.) } \\
\text { Roscoe ex Sm. }\end{array}$ & Zingiberaceae \\
\hline 33 & rom & Padi & Oryza sativa $\mathrm{L}$. & Poac \\
\hline 34 & Ungke & Rimbang & Solanum torvum $\mathrm{Sw}$. & Solanaceae \\
\hline $0-$ & Teh & Teh & $\begin{array}{l}\text { Cammellia sinensis (L.) } \\
\text { Kuntze. }\end{array}$ & Theaceae \\
\hline 36 & Bungle & Banglai & $\begin{array}{l}\text { Zingiber cassumunar } \\
\text { Roxb. }\end{array}$ & Zingiberaceae \\
\hline 3 & Tingkem & Pohon gadog & $\begin{array}{l}\text { Bischofia javanica } \\
\text { Blume. }\end{array}$ & Phyllanthaceae \\
\hline 38 & Gunur & $\mathrm{Ku}$ & $\begin{array}{l}\text { Benincasa hispida } \\
\text { (ThunB.) Cogn }\end{array}$ & jitaceae \\
\hline 39 & Lasun ilang & Bawang merah & Allium сера $\mathrm{L}$. & Amarylidaceae \\
\hline & Rempon & Kangkung & Ipomoea reptana & Convolvulaceae \\
\hline
\end{tabular}

Berdasarkan Tabel 1 dapat dilihat bahwa jenis tumbuhan tradisional sebagai obat diare di Kecamatan Terangun Kabupaten Gayo Lues terdapat 40 jenis tumbuhan dan 28 familia Zingiberaceae, Rutaceae, Graminae,
Melastomaceae, Rubaceae, Musaceae, Anocardiaceae, Mirtaceae, Myristicaceae, Arecaceae, Lamiaceae, Moraceae, Apiaceae, Piperaceae, Alliaceae, Piperaceae, Lauraceae, Annonaceae, Cucurbitaceae, 
Convolvulaceae, Loranthaceae, Sapindaceae,

Euphorbeaceae, Poaceae, Solanaceae,

Theaceae, Phyllanthaceae, Amarylidaceae.

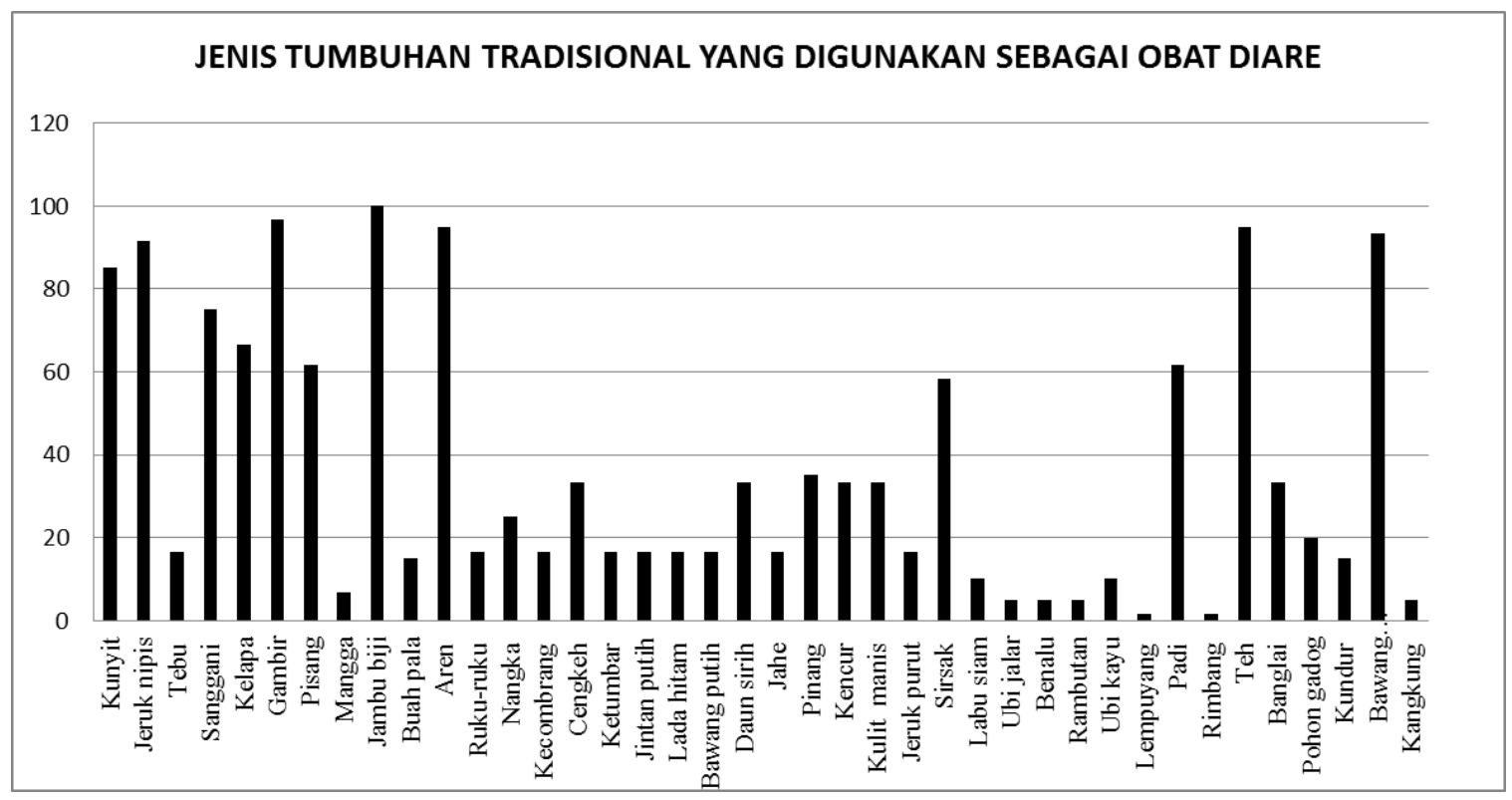

Gambar 1. Diagram Persentase Jenis Tumbuhan Tradisional Sebagai Obat Diare Di Kecamatan Terangun Kabupaten Gayo Lues.

Gambar 1 menunjukan bahwa

tumbuah jambu binji adalah jenis tumbuhan yang paling sering dimanfaatkan oleh seluruh responden.

\section{Bagian Tumbuhan Tradisional yang} Dijadikan Sebagai Obat Diare
Berdasarkan dari penelitian yang telah dilakukan bagian tumbuhan yang dapat dijadikan sebagai obat diare yaitu bagian rimpang, batang, siung, daun, buah dan biji. Data didapatkan dari hasil wawancara dengan responden dapat dilihat pada Gambar 2. 


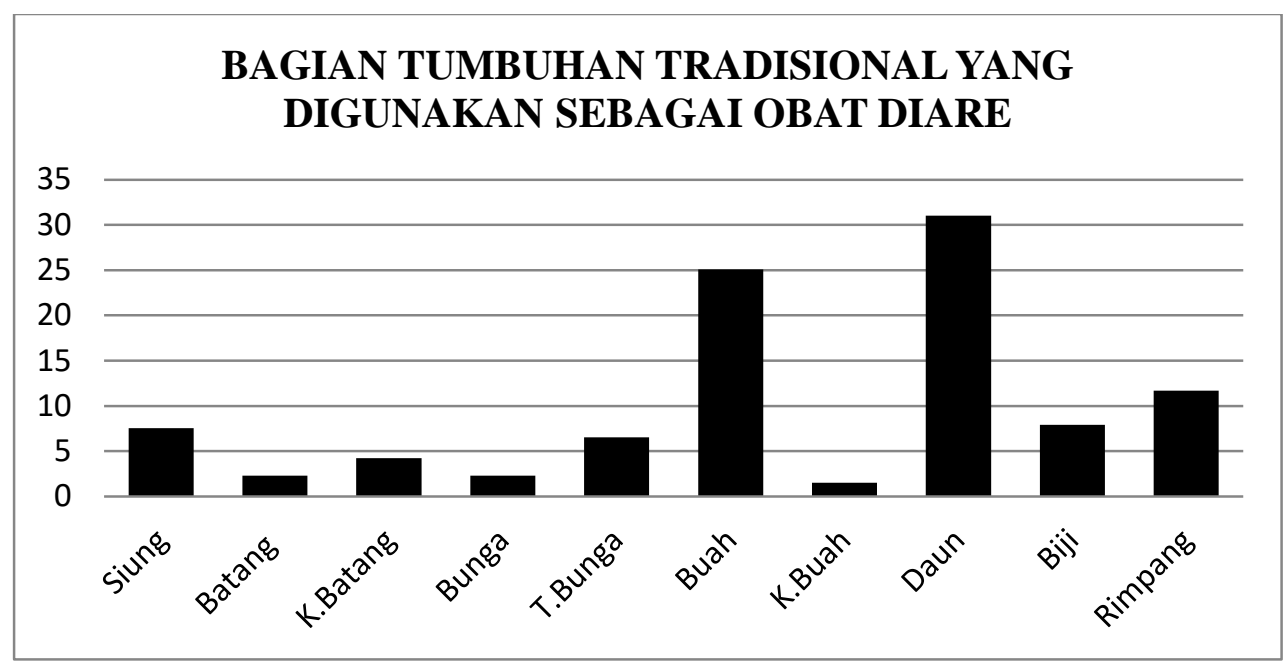

Gambar 2. Diagram Persentase Bagian Tumbuhan Tradisional Yang Dimanfaakan Sebagai Obat Diare

Gambar 2 menunjukan bahwa bagian tumbuhan yang paling banyak dimanfaatkan adalah bagian buah $25,06 \%$ dan daun $31,01 \%$.

Cara Pengolahan dan penggunaan Tumbuhan Tradisional Yang Digunakan Sebagai Obat Diare Di Kecamatan Terangun Kabupaten Gayo Lues
Cara penolahan dan pengggunaan tumbuhan tradisional untuk obat diare di kecamatan terangun ada beberapa cara yaitu digiling, diminum, dimakan, dimakan mentah, dioles dan diremas. Data cara pengolahan dan penggunaan didapatkan dari hasil wawancara pada responden dapat dilihat pada Gambar 3.

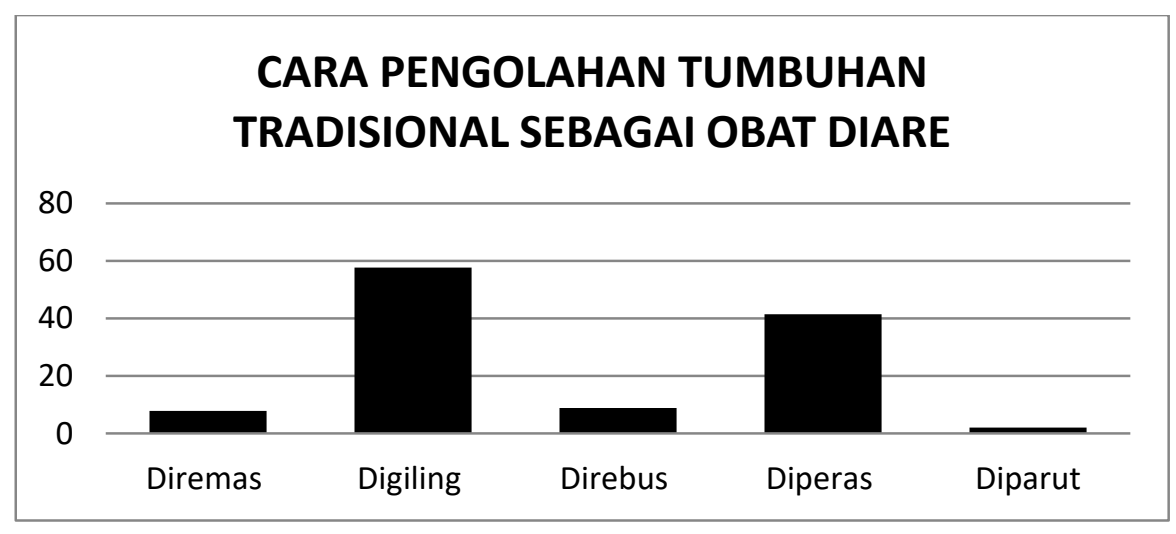

Gambar 3. Diagram Cara Pengolahan Tumbuhan Tradisioanl Sebagai Obat Diare 
Berdasarkan Gambar 3 cara obat diare paling banyak dilakukan adalah pengolahan tumbuhan tradisioanl sebagai dengan digiling yaitu sebanyak 57,67\%.

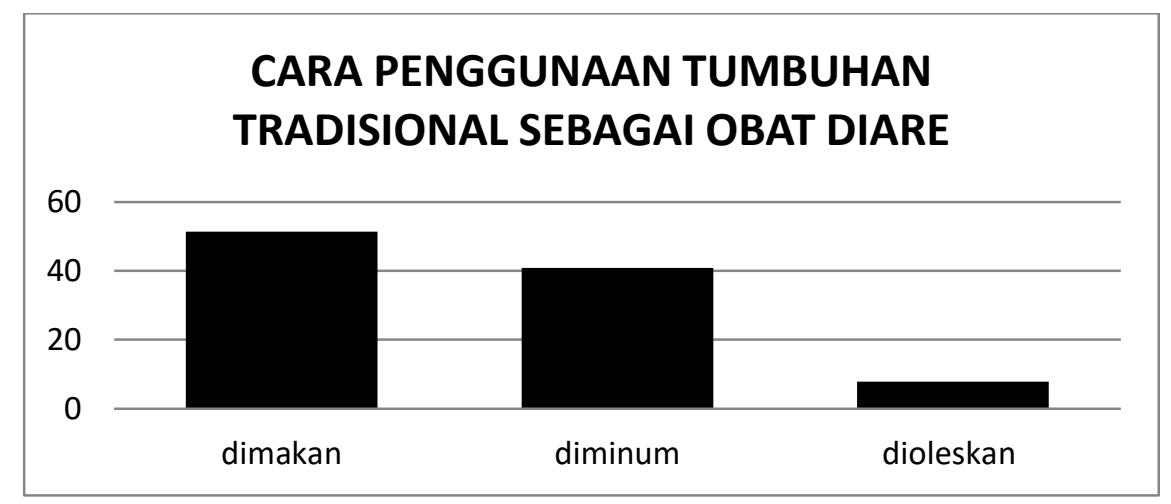

Gambar 4. Diagram Cara Pemanfaatan Tumbuhan Tradisioanl Sebagai Obat Diare

Berdasarkan gambar 4. menunjukan

bahwa cara pemanfaatan tumbuhan tradisional sebagai obat diare paling banyak dilalukan dengan cara dimakan yaitu $51,37 \%$.

Persepsi Responden Terhadap Pemanfaatan Tumbuhan Tradisional Sebagai Obat Diare
Persepsi responden tentang alasan pemanfaatan tumbuhan tersebut di 6 desa dalam wilayah Kecamatan Terangun Kabupaten Gayo Lues. Adapun persepsi responden berdasarkan dari hasil kuisioner yang telah disebarkan dapat dilihat pada Tabel 2.

Tabel 2. Persepsi Responden Terhadap Pemanfaatan Tumbuhan Tradisional Sebagai Obat Diare

\begin{tabular}{|c|c|c|}
\hline No & Pertanyaan & Persentase \\
\hline (1) & (2) & (3) \\
\hline 1 & Tumbuhan tradisional mudah didapatkan & $93 \%$ \\
\hline 2 & $\begin{array}{l}\text { Tumbuhan tradisional susah dikonsumsi karena memiliki rasa } \\
\text { yang pahit }\end{array}$ & $70,00 \%$ \\
\hline 3 & Sediaan obat tradisional menarik & $80,67 \%$ \\
\hline 4 & $\begin{array}{l}\text { Tumbuhan tradisional sudah dipercaya secara turun temurun } \\
\text { untuk mengobati diare }\end{array}$ & $92 \%$ \\
\hline 5 & $\begin{array}{l}\text { Penggunaan tumbuhan tradisional sebagai obat diare dapat } \\
\text { memusnahkan tumbuhan tradisional }\end{array}$ & $82,67 \%$ \\
\hline 6 & $\begin{array}{l}\text { Penggunaan tumbuhan tradisional sebagai obat diare sekaligus } \\
\text { untuk membudidayakan tumbuhan sebagai obat }\end{array}$ & $89.33 \%$ \\
\hline 7 & Back to nature (kembali ke alam) & $90,67 \%$ \\
\hline 8 & Harga obat tradisional lebih murah & $92,67 \%$ \\
\hline
\end{tabular}


9

tinggal

10 Tumbuhan tradisional tidak memiliki efek samping

11 Diare sembuh dengan obat modern

12 Tidak percaya bahwa tumbuh menyembuhkan diare

13 Tumbuhan tradisional memiliki efek ketergantungan untuk obat diare

14 Tumbuhan tradisional dijamin aman (halal) untuk mengobati diare

15 Percaya akan khasiat tumbuhan tradisional sebagai obat diare

16 Tumbuhan tradisional sulit didapatkan

17 Tumbuhan tradisional memiliki efek samping

18 Tumbuhan tradisional tidak aman untuk mengobati diare
$77,67 \%$

$87,33 \%$

$78,67 \%$

$90 \%$

$79,33 \%$

$99,33 \%$

$91,67 \%$

$74,33 \%$

$92 \%$

$90 \%$

\section{Sumber: Data Primer diolah, 2021}

Berdasarkan Tabel 2 gambaran persepsi responden terhadap pemanfaatan tumbuhan tradisional yang memiliki nilai rerata terbesar adalah pada butir pertanyaan ke 14 yang menyatakan bahwa tumbuhan tradisional dijamin aman (halal) untuk pengobatan diare yaitu $99,33 \%$ dari seluruh responden berjumlah sebanyak 60 orang menyatakan persetujuannya terhadap pertanyaan tersebut. Sedangkan dari seluruh responden menyatakan ketidaksetujuannya terhadap pernyataan bahwa tumbuhan tradisional tidak aman untuk mengobati diare $90 \%$. Kondisi ini menunjukkan mayoritas responden sudah percaya dan terbiasa untuk memanfaatkan tumbuhan tradisional yang ada di sekitar tempat tinggalnya untuk mengobati diare. Pemanfaatan tumbuhan tradisional merupakan pilihan terbaik dari segi kemudahan dalam mendapatkan dan pengolahannya bagi masyarakat yang berada di pedesaan terpencil dan terbatasnya akses sarana kesehatan yang menyediakan obat medis.

\section{Pembahasan}

Berdasarkan hasil penelitian yang dilakukan dikecamatan Terangun Kabupaten Gayo Lues yaitu tumbuhan tradisional yang dapat dijadikan sebagai obat diareb terdapat 40 spesies dari 28 familia. Tumbuhan tradisional untuk pengobatan diare diperoleh dari kebun masyarakat, pekarangan rumah, dari pasar dan tumbuh ditempat liar. Masyarakat mengetahui tumbuhan ini dapat dijadikan sebagai obat yaitu dari tabib yang ada di Kecamatan Terangun Kabupaten Gayo Lues.

\section{Jenis Tumbuhan Tradisional Yang} Digunakan Sebagai Obat Diare 
Jenis tumbuhan tradisional yang digunakan sebagai obat diare oleh masyarakat Kecamatan Terangun Kabupaten Gayo Lues terdapat 40 spesies dan 29 familia. Sedangkan hasil penelitian dari (Diah Permatasari, DKK 2011) di Kecamatan Baturaden Kabupaten Banyumas menyatakan bahwa ditemukan 10 tanaman untuk pengobatan diare adapun jenis tanamannya yaitu jambu biji, kara, ketumbel, kunyit,lengkuas, manggis, nangka, pala, patikan kebo, pepaya. Kemudian menurut Indriani dan Nuning, (2018) Di Sulawesi Selatan ditemukan 30 jenis tumbuhan obat anti diare yang digunakan oleh 48 responden. Tumbuhan obat ini terdiri dari 19 familia dan terbanyak berasal dari familia Zingiberaceae (6 spesies), yaitu Curcuma. aeruginosa, Curcuma longa, Curcuma zanthorriza, Curcuma zedoaria, Kaempferia galanga dan Zingiber zerumbet. Familia ini merupakan sumber daya tumbuhan yang cukup penting dalam menghasilkan berbagai produk untuk obat-obatan.

Berdasarkan Tabel 1 dan Gambar 1 diatas dapat diketahui bahwa terdapat 40 jenis tumbuhan tradisional yang paling sering dimanfaatkan oleh sebagian besar responden, Dari jenis-jenis tumbuhan tradisional tersebut tumbuhan jambu biji adalah jenis tumbuhan yang paling sering dimanfaatkan seluruh responden, dimana persentase pemanfaatannya adalah sebesar 100\%. Dari 40 jenis tumbuhan tradisonal yang pernah digunakan oleh responden tersebut dapat dikategorikan berdasarkan besarnya persentase pemanfaatan dengan kategori sangat tinggi (75\%-100\%) yaitu: jambu biji, gambir, aren, jeruk nipis, teh, bawang merah, sanggani dan kunyit. Sedangkan jenis tumbuhan dengan tingkatan pemanfaatan kategori tinggi (50-75\%) yaitu: kelapa, pisang, padi dan sirsak. Selanjutnya jenis tumbuhan dengan tingkatan pemanfaatan kategori rendah (25\%-50\%) yaitu: pinang, kencur, kulit manis, daun sirih, cengkeh, nangka dan banglai. Sedangkan pada kategori sangat rendah (1\%-25\%) yaitu: pohon gadog, jeruk purut, ruku-ruku, kecombrang, ketumbar, jintan putih, lada hitam, bawang putih, jahe, tebu, pala, ubi kayu, kundur, kangkung, ubi jalar, benalu, rambutan dan rimbang.

Hasil penelitian dari (indriani dan nuning, 2018) di Sulawesi Selatan Pada studi ini tumbuhan obat dengan fidelity level atau nilai penting tertinggi adalah Psidium guajava (41,67\%), disusul Mangifera sp. (8,33\%), Curcuma longa dan C. zedoaria (6,25\%), kemudian Allium cepa, Anacardium occidentale, Syzygium cumini, dan $C$. zanthorrhiza $(4,17 \%)$. Tumbuhan obat 
lainnya memiliki fidelity level 2,08 yang masing-masing hanya digunakan oleh 1 orang hattra saja. Fidelity level ini menunjukkan persentase informan dalam memanfaatkan suatu jenis tumbuhan untuk tujuan utama yang sama. Terdapat $41,67 \%$ hattra yang menggunakan tanaman $P$. guajava untuk mengatasi diare. Nilai UV dan CV tertinggi adalah 0,42 dan 13,84 untuk $P$. guajava. Jenis tumbuhan yang paling penting diketahui berdasarkan jenis tumbuhan yang paling sering digunakan oleh hattra.

\section{Bagian Tubuhan Tradisional Atau Organ yang Digunakan Sebagai Obat Diare}

Dari wawancara dengan responden sebanyak 60 orang didapatkan bahwa terdapat perbedaan dalam pemanfaatan bagian tumbuhan obat. Bagian-bagian yang digunakan adalah akar, batang, daun, buah, biji, rimpang, tangkai bunga dan kulit batang. Sebagian besar pengobatan tradisional dengan tumbuhan obat di Kecamatan Terangun Kabupaten Gayo Lues hanya menggunakan satu bagian dari satu tumbuhan, bagian daunnya saja atau bagian rimpangnya saja. Sedangkan bagian-bagian lain dari tumbuhan tersebut tidak digunakan.

Berdasarkan hasil kuantifikasi data pada Gambar 2 menunjukkan bahwa bagian tumbuhan yang paling banyak dimanfaatkan adalah buah $25,06 \%$ dan daun $31,01 \%$ atau dalam kriteria rendah. Dari sisi konservasi tumbuhan, penggunaan daun dalam jumlah tertentu tidak akan mengganggu kelangsungan hidup tanaman (Noorhidayah, 2006; Setyowati, 2010).

$$
\text { Adapun tumbuhan yang }
$$

dimanfaatkan buahnya sebagai obat diare meliputi: jambu biji, jeruk nipis, kelapa, pisang, pinang. Selanjutnya bagian tumbuhan tradisional yang paling sering dimanfaatkan sebagai obat diare adalah rimpang yaitu sebesar 11,67\% dalam kriteria sangat rendah. Tumbuhan tradisional tersebut adalah: kunyit, jahe, kencur, banglai dan lempuyang. Biji (7,89\%), tangkai bunga (6.25\%), kulit batang $(4,23 \%)$, bunga $(2,29 \%)$ batang $(2,29 \%)$, siung $(7,55 \%)$ serta kulit buah $(1,49 \%)$. Walaupun demikian terdapat beberapa jenis tumbuhan yang hampir semua bagian dari tumbuhan tersebut digunakan untuk pengobatan diare. Salah satunya buah pala dan jambu biji, dari buah pala bagian yang digunakan biji, kulit buah dan daun sedangkan dari jambu biji bagian yang digunakan daun, kulit batang dan buah. Tumbuhan ini mengandung minyak atsiri selain itu juga mengandung miristin yang bersifat menenangkan sehingga orang yang terkena diare akan lebih tenang Diah, dkk, (2011). 
Hasil penelitian dari Indriani dan Nuning, (2018) terdapat dua tumbuhan yang menggunakan dua bagian tumbuhan secara terpisah, yaitu Psidium guajava (daun dan kulit buah) dan Syzygyum cumini (daun dan kulit batang). Kemudian terdapat satu tumbuhan yang menggunakan dua bagian dalam satu ramuan, yaitu Palaquium sp. (daun dan kulit batang). Gambar 2 menunjukkan bahwa daun merupakan bagian tanaman yang paling banyak digunakan dalam ramuan anti diare, karena daun mudah diperoleh dalam jumlah besar dan tersedia sepanjang waktu tanpa bergantung terhadap musim. Bagian tumbuhan yang paling banyak digunakan setelah daun berturut-turut adalah rimpang, kulit batang, kulit buah, kemudian batang, buah, umbi, biji dan herba

\section{Cara Pengolahan dan Pemanfaatan Tumbuhan Tradisional sebagai Obat Diare}

Pada penelitian ini cara pengolahan dan pemanfaatan tumbuhan tradisional sebagai obat diare paling sering dilakukan dengan cara digiling yaitu 57,67\% (kriteria tinggi) dan selebihnya diperas, diparut, direbus dan diremas. Tumbuhan obat tradisional yang pengolahannya dengan cara digiling yaitu terdapat pada kunyit, bawang merah, gula pasir, jeruk nipis, nangka, gula merah, buah pala, daun sirih, banglai, kencur, kulit manis, cengkeh, pinang, gambir, jeruk purut, bawang putih, ketumbar, lada hitam, jintan putih, lempuyang, kunyitr, jambu biji dan ruku-ruku. Tumbuhan obat yang pengolahannya direbus $8,92 \%$ (kriteria sangat rendah) yaitu kunyit dan jahe. Tumbuhan yang pengolahannya diperas $41,47 \%$ (kriteria rendah) yaitu Kelapa,mangga, jambu biji, dan kecombrang. Tumbuhan yang pengolahannya dengan cara di parut $2 \%$ (kriteria sangat rendah) yaitu labu siam dan kundur. Tumbuhan yang pengolahannya dengan cara diremas 7,78\% (kriteria sangat rendah) yaitu Rambutan, ubi kayu, ubi jalar, benalu, kangkung, dan kelapa. dimana terangkum pada Gambar 3.

Cara pemanfaatannya tumbuhan obat yang paling banyak dilakukan oleh masyarakat kecamatan terangun kabupaten gayo lues dalam pengobatan diare adalah dengan cara dimakan. Meurut (indriani dan nuning, 2018) dalam penelitiannya menunjukkan tiga cara pemakaian ramuan, yaitu dengan pemakaian dalam (diminum), luar (dibalurkan ke perut) dan kombinasi keduanya. Komposisi ramuan juga beragam, terdapat ramuan yang terdiri dari satu tumbuhan saja (ramuan tunggal), dan ada yang terdiri dari beberapa jenis tumbuhan (ramuan). 
Berdasarkan hasil persentase menunjukan bahwa pemanfaatan tumbuhan dengan cara dimakan 51,37\% (kriteria tinggi), diminum 40,85\%(kriteria rendah) dan dioleskan pada bagian perut $7,78 \%$ (kriteria sangat rendah) dimana terangkum pada Gambar 4.

Salah satu cara penggunaan tumbuhan tradisional untuk mengobati diare adalah dengan dimakan. Salah satu jenis tumbuhan tradisional dengan cara dimakan adalah tumbuhan nangka. Buah nangka mempunyai kandungan vitamin B, kalsium, protein yang dapat mengembalikan tenaga seperti semula setelah terkena diare. Selain itu nangka juga mempunyai kandungan alkaloid, flavonoid yang merupakan senyawa fenol. Kandungan senyawa yang berperan adalah alkaloid, karena alkaloid bisa digunakan sebagai antibakteri dengan mengganggu terbentuknya jembatan silang komponen penyusun peptidoglikan pada sel bakteri. Sehingga lapisan dinding sel tidak terbentuk secara utuh dan menyebabkan kematian sel tersebut . caranya, nangka yang masih muda di makan bersama dengan garam. Dengan cara seperti itu kandungan yang ada pada nangka tidak akan hilang (Diah, dkk, 2011:44-64).

\section{Persepsi Responden Terhadap Pemanfaatan Tumbuhan Tradisional Sebagai Obat Diare}

Berdasarkan data pada tabel 2 persepsi masyarakat kecamatan terangun kabupaten gayo lues mengenai pemanfaatan tumbuhan tradisional sebagai obat dire persepsi yang banyak timbul adalah tumbuhan tradisional dijamin aman (halal) untuk obat diare 98,33\% (sangat setuju) dan diketahui sisanya yaitu $1,67 \%$ responden menolak pernyataan tersebut hal ini sejalan dengan penelitian yang telah dilakukan oleh (Ratna sari dkk, 2019) di Kelurahan Simpang Baru Kecamatan Taman Kota Pekan Baru.

Dari penelitian ini dapat diketahui masih banyak masyarakat meyakini bahwa persepsi mereka mengenai khasiat obat tradisional yang lebih aman karena terbuat dari bahan alami dan apabila dikonsumsi dalam jangka panjang tidak akan menimbulkan efek samping dan telah dibuktikan dengan penelitian lain bahwa persepsi label halal berpengaruh singnifikan terhadap keputusan pembelian (Alim,dkk.2018)

Persepsi yang banyak timbul di masyarakat selanjutnya mengenai pemanfaatan tumbuhan tradisional sebagai obat diare adalah tumbuhan tradisional mudah didapatkan yaitu $93 \%$ atau sangat 
setuju. Dimana masyarakat kecamatan terangun kabupaten gayo lues banyak menanam dan membudidayakan tanaman obat disekitar rumah mereka dan memiliki tempat tinggal yang berdekatan dengan hutan sehingga mudah mendapatkan tumbuhan tradisional sebagai obat diare. Sedangkan dari seluruh responden menyatakan ketidaksetujuannya terhadap pernyataan bahwa tumbuhan tradisional tidak aman untuk mengobati diare $32 \%$ atau tidak setuju. Kondisi ini menunjukkan mayoritas responden sudah percaya dan terbiasa untuk memanfaatkan tumbuhan tradisional yang ada di sekitar tempat tinggalnya untuk mengobati diare. Pemanfaatan tumbuhan tradisional merupakan pilihan terbaik dari segi kemudahan dalam mendapatkan dan pengolahannya bagi masyarakat yang berada di pedesaan terpencil dan terbatasnya akses sarana kesehatan yang menyediakan obat medis.

\section{PENUTUP}

\section{Simpulan}

Berdasarkan hasil penelitian yang telah dilakukan, maka dapat diperoleh beberapa simpulan, diantaranya :

1. Jenis-jenis tumbuhan tradisional yang digunakan sebagai obat diare di Kecamatan Terangun Kabupaten Gayo
Lues terdapat 40 jenis tumbuhan dari 28 familia. Jenis tumbuhan paling banyak digunakan yaitu jambu biji dengan persentase $100 \%$ atau kriteria sangat tinggi

2. Bagian atau organ tumbuhan obat yang digunakan sebagai obat diare yaitu kulit batang, buah, biji dan kulit batang. Bagian tumbuhan yang paling banyak digunakan yaitu bagian daun dengan persentase $31 \%$ atau dengan kriteria rendah

3. Cara pengolahan tumbuhan tradisional sebagai obat diara dengan cara digiling, direbus, diremas dan diperas. Cara pengolahan tumbuhan sebagai obat diare paling banyak dilakukan dengan cara digiling dengan persentase $57,67 \%$ atau dengan kriteria tinggi

4. Persepsi masyarakat menggunakan tumbuhan tradisional untuk obat diare diKecamatan Terangun Kabupaten Gayo Lues bahwa persepsi yang banyak timbul adalah tumbuhan tradisional untuk mengobati diare dengan persentase 98,33\% atau dengan kriteria sangat setuju.

\section{Saran}

Diharapkan dari hasil penelitian ini dapat bermanfaat bagi penulis dan pembaca serta menjadi pedoman dasar bagi penelitian 
selanjutnya dan memiliki ruang lingkup yang lebih luas. Penelitian ini tidak dilakukan diseluruh Kecamatan Terangun Kabupaten Gayo Lues dimana hanya melakukan dibeberapa desa yang berjumlah 6 desa yaitu desa Blangkuncir, desa Terlis, desa Persada Tongra, desa Lestari, desa Rime Raya dan desa Gewat dengan masing-masing 10 responden terdiri dari laki-laki dan perempuan dan kisaran umur yang berbedabeda. Oleh sebab itu diharapkan kepada para peneliti selanjutnya dapat menyempurnakan dan melakukan penelitian yang lebih baik.

\section{DAFTAR PUSTAKA}

Alim, S,A., Mawardi, M.K., Bafadal, A.S. 2018. Pengaruh Persepsi Label Halal dan Kualitas Produk Terhadap Keputusan Pembelian Produk Fesyen. Malang: Jurnal Administrasi Bisnis.

Dewi, R. S., Sri, F. N., Fina Aryani., Erniza, P, Tiara, T. A. 2019. Persepsi Masyarakat Mengenai Obat Tradisional Di Kelurahan Simpang Baru Kecamatan Tampan Kota Pekanbaru. Jurnal Penelitian Farmasi Indonesia. 8(2), 2656-3614.

Larasati TA., WA Hardita., dan IK Dewi. 2016. Aktivitas Musa paradisiaca dalam Terapi Diare Akut pada Anak TA. JK Unila, Volume 1 Nomor 2.
Mustofa, F. I., Nuning Rahmawati. 2018. Studi Etnofarmakologi Tumbuhan Obat yang Digunakan oleh Penyehat Tradisional untuk Mengatasi Diare di Sulawesi Selatan. Jurnal Tumbuhan Obat Indonesia.11(2).17-23.

Noorhidayah, N. 2006. Potensi dan Keanekaragaman Tumbuhan obat di Hutan Kalimantan dan Upaya Konservasinya. Jurnal Analisis Kebijakan Kehutanan, 3, 95-107. https://doi.org/10.20886/jakk.2006.3. 2.95-107

Setyowati, F. 2010. ETNOFARMAKOLOGI DAN PEMAKAIAN TANAMAN OBAT SUKU DAYAK TUNJUNG DI KALIMANTAN TIMUR. Media Litbang Kesehatan., 20(3), 104-112.

Permatasari, D., D, dan Dwi, H. 2011. Studi Etnofarmakologi Obat Tradisional Sebagai Anti Diare di Kecamatan Baturaden Kabupaten Banyumas. Pharmacy, Vol.08 No. 01.

Rapilu, B dan Theopilus, W. 2018. Studi Pemanfaatan Tumbuhan Obat Tradisional Oleh Masyarakat Suku Oirata Pulau Kisar Kecamatan PulauPulau Terselatan Kabupaten Maluku Barat Daya. Volume.5. nomor 1. 